\title{
O PROCEDIMENTO GENEALÓGICO DE NIETZSCHE
}

Antonio Edmilson Paschoal *

\section{Intıod uçã o}

O presente artigo tem por finalidade apresentar de forma sucinta alguns pontos para uma reflexão sobre o procedimento genealógico de Nietzsche. $\mathrm{O}$ texto base, que modificado deu lugar a este artigo, surgiu como parte introdutória de uma tese de doutorado intitulada "A dinâmica da vontade de poder como proposição moral nos escritos de Nietzsche". Sua publicação isolada, neste momento, tem por objetivo ampliar algumas discussões, que se desenvolvem no curso de Mestrado em Educação da PUCPR, ligadas especialmente ao programa "Epistemologia e metodologia da pesquisa em educação". Nesse contexto específico, ele se apresenta como um subsídio para a reflexão acerca da relação entre a busca do conhecimento e formas de exercício de poder.

O que Nietzsche entende por genealogia não pode ser reduzido a uma fórmula definida e estática. Mesmo a clássica compreensão da genealogia como a investigação das condições que permitiram a origem, transformação, deslocamento e desaparecimento de formas, discursos ou instituições em relações de poder, como se verá, não é suficiente para dar conta do procedimento nietzschiano, especialmente em se tratando de uma análise desse procedimento nos escritos de 1886 a 1887. Nietzsche os articula como o exercício de uma forma de vontade de poder e como uma arte de interpretação, que ultrapassa em muito qualquer associação com a idéia de pesquisa, produção e acúmulo de conhecimentos.

Quanto à sua construção, este texto terá início por uma aproximação ao termo "genealogia", seu surgimento, significado e a forma como é apreen-

* Professor/Pesquisador do Programa de Pós-Graduação em Educação da PUCPR 
dido e utilizado por Nietzsche; em seguida, no item genealogia, genealogista e um primeiro contato com a questão dos valores, será feita uma abordagem do que caracteriza uma "investigação" como sendo genealógica e o papel próprio do genealogista que, a partir da tomada do termo "genealogia" por Nietzsche, dificilmente se afasta do contexto de uma axiologia. Mais adiante, terá lugar, em termos comparativos, uma distinção entre a genealogia de Nietzsche e a de outros genealogistas da moral; em seguida, nos itens a linguagem como problema e a relação entre a genealogia e a história, serão analisados os limites que uma compreensão tradicional da linguagem e da história impõe à pesquisa genealógica e a forma como Nietzsche as concebe e se apropria delas em seu trabalho.

\section{0 temo "genealogia"}

O termo "gen", ou "gene", que juntamente com o sufixo "logia" (estudo, conhecimento), compõe o termo "genealogia", designa, modernamente, os cromossomos nos quais se localizam os fatores hereditários, a herança dos antepassados na espécie, que determina (geneticamente) a formação da geração atual ou de um indivíduo. Em sua origem grega, o termo "genealogia" pode ser associado ao radical "geneá", que designa "gênero", "espécie" ou, mais propriamente, "geração" e "família"; e ao radical "génos", que designa "nascimento", "origem". Da composição desses radicais com o sufixo "logia" tem-se o significado do termo "genealogia" na língua grega, que é "linhagem", "descendência" ou , mais especificamente, o estudo dos progenitores e ascendentes de um indivíduo ou família.

Na língua alemã, a utilização do termo "genealogia" procede do século XVII e tem seu uso associado ao conhecimento acerca da linhagem dos antepassados que constituem o "tronco" de uma família, como se pode verificar pela moderna utilização do termo.

Entendido como pesquisa sociológica para a definição de traços de parentesco entre famílias e pessoas, o termo "genealogia" teve dois significados distintos. Um primeiro, mais próprio de sociedades marcadas por laços de consangüinidade no estabelecimento das relações básicas de hierarquia, nas quais a pesquisa genealógica se associa à garantia de certos direitos e se faz para comprovar a participação de alguns indivíduos em determinadas famílias, normalmente de ascendência nobre. Um segundo, mais moderno, que toma o estudo genealógico dos traços de uma família, seja ela pobre ou rica, para auxiliar na compreensão de um determinado agrupamento social pelo conhecimento dos traços básicos de uma ou mais famílias, o que visa facilitar a compreensão das relações entre famílias e do aparecimento de solidariedades inesperadas, resistências imprevisíveis ou reações imponderadas. Nesse 
sentido genérico, de pesquisa sociológica, a genealogia pode ser vertical ou horizontal. Entende-se por uma pesquisa genealógica vertical tanto a busca de um ascendente quanto de um descendente, conforme se queira estabelecer os antepassados de um determinado indivíduo, ou a descendência de um determinado progenitor. Por sua vez, uma pesquisa genealógica horizontal aponta para o estabelecimento de laços de parentesco e relações entre famílias.

Por esse primeiro e rápido contato com o termo "genealogia", já se tem a idéia de uma busca do conhecimento das "origens", daquelas "marcas" inscritas como sintomas nos corpos das gerações presentes; uma busca que remete ao passado, a gerações que foram, por exemplo, submetidas a dominações, que passaram por guerras ou por longas etapas de privações ou, diferentemente, por estágios de fartura. Falhas e acertos vão constituindo os traços de uma família e se inscrevem no herdeiro. E inscrições não ocorrem graças a algum antepassado divino, mas à pluralidade de elementos que se misturaram com a permanente entrada em cena de novas figuras e consequentemente novos "gens", os quais se associaram até formar a atual "família". É deste movimento de aparecimento de marcas que o genealogista procura fazer a leitura até onde pode atingir, antes que se perca na escuridão do passado.

Na filosofia, é Nietzsche quem utiliza pela primeira vez o termo "genealogia", e o toma preservando seu sentido de busca de herança dos antepassados, de conhecimentos sobre a origem daquele que ainda vive. Mas, quando se trata da utilização do termo "genealogia" por Nietzsche, deve-se acrescentar à idéia de "pesquisa" (melhor traduzida pelo termo "investigação"), da busca pela origem e pela herança deixada pelos antepassados, o seu engajamento, a partir do qual sua investigação ganha forma.

Além da própria idéia de busca das "origens", pode-se também inferir, agora, a partir da utilização do termo "genealogia" antes de Nietzsche, alguns pontos que corresponderão ao conceito, na forma como ele passará a utilizá-lo. Primeiro: a busca pela entrada em cena das marcas que constituem a geração atual não remete a unidades, mas a pluralidades que se agitam e se confrontam na dinamicidade das "origens" do que temos hoje. Segundo: para resistir ao seu necessário destino, que é finalmente perder, no escuro do passado, as "pistas", os "fios condutores" da entrada em cena daquilo que produziu a herança - o fio das emergências que se multiplicam numa progressão geométrica, quanto mais se avança na própria procura - o genealogista deve ser cuidadoso na coleta de dados, deve reuni-los de forma meticulosa no "cinza" dos documentos e, ao mesmo tempo, admitir que sua pesquisa supõe um trabalho com hipóteses, com perspectivas, que são as únicas que podem caminhar até lá, onde a falta de documentos sobre a "origem" torna o olhar impossível. Terceiro: a pesquisa sobre uma família normalmente se faz, ou é 
encomendada, por alguém da própria família, por alguém diretamente interessado nos resultados da pesquisa. Ele, o genealogista é, portanto, parte da família. Faz a genealogia de si mesmo e não pode negar o solo de onde parte sua pesquisa, pois é este solo mesmo que ele procura entender.

\section{Genealogia, genealogista e a questão dos valores}

O procedimento genealógico, apontado anteriormente como a ação própria do genealogista, tem sua origem, em Nietzsche, como uma contraposição, uma resposta efetiva à tendência ao conformismo niilista do homem moderno. Segundo Nietzsche, na raiz dessa tendência encontra-se um problema axiológico: a tentativa de cristalização de um conjunto de valores que possui, como meta, a auto-diminuição do homem e, como uma de suas estratégias, para se perpetuar no "palco dos acontecimentos", o reforço à tendência de não se colocar mais a moral e os valores em questão. Portanto, a genealogia tem sua emergência diante da necessidade de se recolocar em movimento o que tende a se estagnar, a se converter em "água parada".

Outra face desse mesmo problema é a forma como os filósofos, por exemplo, Kant e Hegel, colocam-se diante dos valores estabelecidos no Ocidente, sem se perguntarem, em momento algum, pelo valor desses valores; tomam-nos como pressupostos intocáveis e os utilizam para estabelecer suas fórmulas sobre a moral, a ciência, a política etc. A partir do momento em que assumem os valores como sendo anteriormente dados ora por Deus, ora pela natureza, ora pela razão, sua labuta passa a consistir, por um lado, em justificá-los e, por outro, em torná-los compreensíveis, pensáveis, racionais. Por esta característica de se colocarem a serviço de valores anteriormente dados é que Nietzsche os denomina de "trabalhadores filosóficos" .

Diferentemente do procedimento desses "filósofos", o genealogista toma como tarefa revirar as profundezas, numa análise das forças em jogo no momento da emergência dos valores e de sua manutenção enquanto valores. Pressupondo que "le haut et le bas, le noble et le vil ne sont pas des valeurs, mais représentent l'élément différentiel dont dérive la valeur des valeurs ellesmêmes" , o genealogista irá se ocupar da busca deste "elemento diferencial", que se encontra na "origem" de tais valores e de sua manutenção.

Por seu ato básico de colocar o valor dos valores em questão, 0 genealogista já está rejeitando a postura de "serviçal da filosofia" e procurando realizar a tarefa própria do filósofo, qual seja a de criar valores. Mas, para isto, ele precisa ter em si também um "elemento diferencial", um tipo de vontade de poder nobre, que lhe dê a autoridade de se colocar diante dos valores com o mesmo respeito que "golpes de martelo" podem ter. Ele precisa negar os 
pressupostos estabelecidos, ou não será diferente dos "trabalhadores filosóficos", pois o "brandir de seu martelo" não é uma banal ação destruidora que deixaria em ruínas aquilo que na concepção da filosofia tradicional "era"; e estas mesmas ruínas, à mercê das infindáveis interpretações de um relativismo sem sentido. A ação do martelo é antes uma forma de demolir uma prisão, de revelar uma figura que se esconde na pedra, na qual dorme "uma imagem, a imagem das imagens". Ela é, portanto, ação de uma vontade criadora, plástica, como define sua ação o próprio Nietzsche ao afirmar: "...em direção ao homem, com constância para o novo, leva-me minha fervorosa vontade de criar; assim é levado meu martelo à pedra" . Trata-se, portanto, de um projeto construtivo, no qual o procedimento genealógico se articula com uma "transvaloração [e não uma mera destruição] de todos os valores". A ação criadora do genealogista se assemelha à ação da "criança de Heráclito", e o homem, a pedra à qual dirige seu martelo, "desperta por si um interesse, uma tensão, uma esperança, quase uma certeza, como se com ele algo se anunciasse, algo se preparasse, como se o homem não fosse uma meta, mas apenas um caminho, um incidente, uma ponte, uma grande promessa..." . Por seu "elemento diferencial" o genealogista se insere na paradoxal história do homem para levá-la ainda mais adiante.

O filósofo, como Nietzsche o concebe, é um determinador, um criador de valores, e seu agir, como alguém que dá nomes, pressupõe um "pathos de distância" . Uma necessária tomada de distância da massa disforme, que se constituiu em nome do "bem-estar geral", para poder legislar. Ele precisa ter por princípio que sua ação não pressupõe justificativas, que ela se justifica em si mesma, em sua obra, em sua própria ação plasmadora. E é para poder plasmar que o filósofo tem que arriscar o diferente, tomar como hipótese o que é estranho à moral, num esforço por ser diferente daquilo que o constitui, por se afastar de seus pressupostos. Este é o esforço de Nietzsche que, apesar de seu próprio "solo", do próprio comprometimento com suas "raízes", com os valores "dados", enfim, com a cultura de seu tempo, procura apontar algo diferente. E mais, procura fazê-lo a partir justamente deste "solo", não se comprometendo com os subjugamentos passados, mas tomando-os e tomando também aos próprios "operários da filosofia" como instrumentos, meios para seu fim. A Nietzsche só é possível atingir tal grau de liberdade sendo um "imoralista".

Pode-se aqui, num rápido parênteses, rever a forma pela qual Nietzsche vai configurando o termo "genealogia", indo para além de um "conhecimento" genealógico das origens, desprendendo-se do termo "pesquisa" no sentido de simples acúmulo de informações e também do termo "método", considerado como "caminho", "via" mais apropriada para se chegar a uma verdade que se encontraria perdida no passado. Com Nietzsche a "vontade de verdade" da genealogia é "vontade de poder" . Ela se exprime simultaneamente como crítica e como ação criadora. 
Ainda num sentido muito específico do termo no pensamento de Nietzsche, a genealogia é interpretação. Ela se propõe a reinterpretar, a inverter o sentido da interpretação dominante. Assim sugere Nietzsche: "e bem poderia vir alguém que, com intenção e arte de interpretação opostas, soubesse ler na mesma natureza, tendo em vista os mesmos fenômenos, precisamente a imposição tiranicamente impiedosa e inexorável de reivindicações de poder" , mostrando, tanto pela contraposição dada pela inversão quanto pela possibilidade mesmo da inversão, que os valores tomados como "dados" pelos filósofos são também "interpretação e não texto", um "estado de forças" . E, diante da possibilidade, de mesmo à sua "perspectiva" se contra-argumentar que também ela não é texto, mas interpretação, responde Nietzsche: "bem, tanto melhor!" . O que ele pretende é tomar as regras do jogo, assumir o próprio "impulso tirânico" da filosofia, sem, contudo, querer ocultar o solo de onde se exprime, sua realidade perspectiva. Com isto, Nietzsche não se propõe simplesmente a "desmascarar" a filosofia ou a pretensão à verdade dos filósofos; como estes, pretende portar uma máscara (tendendo mesmo para uma caricatura) como forma de mostrar que todas as demais filosofias também são máscaras. A diferença é que ele não procura cristalizar sua perspectiva como uma "verdade" , com o que estaria negando o jogo das perspectivas, mas fazer seguir o próprio jogo, mantê-lo em movimento - se é que ele poderia parar. Nietzsche atua como uma vontade de poder ativa que torna o interpretar ativo, que pelo seu dizer "sim" ao próprio jogo quer oferecer-lhe a possibilidade de dar seus próximos passos e com isto levar o homem moderno à sua auto-superação. O genealogista Nietzsche não pode dispensar, por exemplo, o texto de Para a Genealogia da Moral, pois carece dele, assim como carece do "cinza" dos documentos. Mas o próprio texto se compõe como parte de um procedimento. Ele, portanto, antes de querer "provar" alguma coisa, alguma "verdade", fixando-a num "texto", busca servir-se do texto para se apossar das regras do jogo, para, "ao seu modo, fazer guerra". Também seu texto é apenas "sinal" do atuar de uma determinada forma de vontade de poder.

\section{Difeenças ente a genealogia de Nietzsche e a deooutr genealogistas da moral}

Nietzsche não nega o valor de outros pesquisadores que se ocuparam da origem dos valores morais, mas faz constante menção, por exemplo, aos genealogistas ingleses e ao Dr. Paul Rée. Aos primeiros, por terem sido os responsáveis, até então, pelas "únicas tentativas de reconstituir a gênese da moral" ; ao Dr. Paul Rée, por ter despertado nele o primeiro impulso para divulgar também suas especulações sobre a moral. 
Referindo-se particularmente aos genealogistas ingleses, Nietzsche afirma que seu problema começa quando se propõem a buscar a origem do conceito "bom" naquilo que primeiramente foi útil e nas ações não egoístas. Com o passar do tempo, pelo hábito e pelo esquecimento, estas ações teriam se distanciado de suas origens e passado a ser consideradas como boas em si, num movimento "azul", sem grandes embates ou rupturas. Segundo Nietzsche, esse gesto inicial básico já é suficiente para descaracterizar esta pesquisa como uma genealogia.

Os genealogistas acreditam que, pelo fato de não tomarem por finalidade um "bem" metafísico, estariam se opondo à metafísica e fazendo ciência. Mas seu procedimento em relação à moral revela apenas "um certo desamor e rancor subterrâneo ao cristianismo (e a Platão)" , além de revelar uma confusão com dois problemas distintos: o da finalidade e o da origem, pois quando tomam uma finalidade atual de algo e a remetem à sua origem, tornam esse algo inteligível em sua origem por meio de sua finalidade atual (por exemplo, que o castigo existe desde sua origem para intimidar ou vingar). Deslocando a utilidade atual de uma ação para a origem da mesma, estão pensando sua finalidade atual como uma causa já estabelecida desde a origem. Algo que, como uma "essência", perpassa o tempo sem sofrer sua ação, desenvolvendo-se linearmente na história para uma perfeição cada vez maior, como um trabalho obscuro de algo pré-estabelecido que procura vir à luz desde o primeiro momento. Eles continuam, assim, presos a um sistema de finalidades, e é por isso que não se livram da camisa de força da metafísica; pelo contrário, são seus sucessores mais modernos e também os mais vulgares. O que os genealogistas ingleses fazem é, para Nietzsche, "tartufície moral, dessa vez oculta sob a forma nova da cientificidade" . Na tentativa de serem diferentes, acabam por jogar a análise dos valores num campo mais baixo, assumem a "perspectiva da rã", sem com isto resolver a questão dos valores ou realmente problematizá-los. Em última instância, o que eles fazem, tomando o princípio da utilidade, é reproduzir a idéia inglesa de utilidade, a moralidade inglesa, que se expressa nas fórmulas: "o 'benefício geral' ou 'a felicidade da maioria'" , que tem por base o igualitarismo e o nivelamento e que é apenas uma das formas de expressão da moral do rebanho.

Tomando os valores atuais e introduzindo-os numa longa história através da qual perseveram, desde sua origem, passando pelo esquecimento, pelo hábito..., na realidade os genealogistas ingleses não os introduzem na história, mas os isentam da ação da história e do tempo. E, ao colocá-los numa anterioridade inalcançável a qualquer crítica, os protegem e os justificam. Após esse movimento de justificativa, o máximo que podem fazer é criticar eventos particulares, instituições, direito etc., em nome dos valores estabelecidos. $\mathrm{O}$ mesmo fazem, por exemplo, Kant, Hegel e Schopenhauer que, como "tra- 
balhadores filosóficos", não criticam os valores morais, mas os respeitam, colocando-os acima de qualquer questionamento.

Para Nietzsche, compreender a utilidade de algo, de uma forma ou de uma instituição, está longe de significar a compreensão de sua gênese. Para ele, "todas as utilidades são apenas indícios" da ação das forças no processo histórico. Uma utilidade atual denota apenas uma apropriação, que ocorre numa cadeia de apropriações e que produz sempre novas utilidades. Para refletir sobre a moral de maneira perigosa, os genealogistas teriam que ser, de alguma forma, "imoralistas": rejeitar os pressupostos da moral, colocar seus valores em questão, olhá-la em sua realidade última, que é indício da ação de uma determinada forma de vontade de poder; o que eles não fazem.

Os genealogistas, com suas especulações, acabam se convertendo em advogados da moral que gostariam de criticar, pois, como os "trabalhadores filosóficos", também eles não descem aos subterrâneos da moral, mas a tornam inteligível e aceitável a partir de uma nova roupagem, uma roupagem científica; o que não significa qualquer combate à moral, mas àquilo que nela é ressecamento, dogmatização, de tal forma que permitem a ela se afirmar e expandir em novos tempos e em circunstâncias que exigem um "decoro científico". Por fim, tomando como pressuposto que, para a moral, é interessante "que o menor número possível de pessoas reflita sobre moral" , eles se colocam, também por essa via indireta, a serviço da moral, pois com suas especulações a tornam algo nada interessante, associando, ainda, o estudo da moral ao esforço por colocar em evidência algo vergonhoso do interior do homem.

Apesar da postura crítica de Nietzsche em relação ao trabalho dos genealogistas, seu esforço não é no sentido de refutar suas teorias, pois, além dos méritos indicados no primeiro parágrafo deste item, eles possuem ainda, para Nietzsche, uma importância como opositores, enquanto sinais de uma vontade de poder nos moldes do ressentimento. Mas não é somente neste sentido que eles são importantes, ou recairíamos na idéia de refutação, e sim pelo fato de serem os representantes mais modernos do travestimento da metafísica e deste trabalho de justificação da moral, bem como por representarem um momento privilegiado da própria tensão que o trabalho de formação de uma moralidade no homem produz. Não se deve, portanto, desprezálos, da mesma forma que não se deve desprezar o trabalho dos "trabalhadores filosóficos", mas "tomar seu trabalho como um meio", tentar dar "a um olhar tão agudo e imparcial uma direção melhor" . A crítica dos valores passa, pois, pela crítica aos que se ocupam da questão dos valores, na própria análise daquilo que eles, sem o saber, oferecem em termos de condições de se pensar para além do próprio homem, motivo pelo qual a genealogia de Nietzsche é também uma genealogia das genealogias. 


\section{A linguagem como qulema}

Considerando o papel da genealogia de desestabilizar entidades fixas, deve-se analisar alguns aspectos da forma como Nietzsche compreende a linguagem e lança mão dela para apresentar sua própria perspectiva. Para elaborar sua perspectiva, Nietzsche precisa desmontar o emaranhado de ficções que ali foi construído. Ele faz essa desmontagem por meio da etimologia, da filologia e da história, numa espécie de "história da emergência do pensamento", que utiliza para mostrar que esses conceitos, tidos como absolutos, também foram "gestados", e para reconduzi-los ao jogo das interpretações, que lhes é próprio.

Nietzsche identifica a história da linguagem como "a história de um processo de abreviação" . Em primeiro lugar, porque, das muitas vivências de um indivíduo, somente aquelas que se repetem inúmeras vezes são compreendidas e designadas por palavras. Em segundo, porque para haver comunicação não basta nomear experiências de um indivíduo, mas devem ser nomeadas as experiências que são comuns a várias pessoas. Em terceiro, porque a necessidade de um bom entendimento entre os indivíduos, no intuito de evitar perigos (mal entendidos), exige que a comunicação seja mantida no campo das expressões mais habituais, de tal forma que "comprendre c'est égaler" . As experiências mais raras não ganham direito de cidadania no campo da linguagem, ao contrário, são as "vivências medianas e vulgares" que, de forma privilegiada, se convertem em linguagem.

Para Nietzsche, a linguagem e a lógica são recursos que o intelecto humano produz e de que lança mão para tornar o mundo formulável, calculável. Por sua vez, o intelecto humano é também algo útil, uma "ferramenta" utilizada com o propósito simples de facilitar a vida .E, se o utiliza, se o homem pensa, isto não significa que ele apreenda qualquer conhecimento (Erkenntnis), muito menos, qualquer "conhecimento em si", mas apenas que faz abstrações, simplificações e reduções, sempre com fins práticos de "designar, de ordenar o acontecer, para torná-lo manejável para nosso uso" .

Com a concepção do intelecto como um instrumento, surge a pergunta: instrumento para que finalidade? Por que tornar o mundo formulável, calculável? Se, num primeiro momento, é aceitável como resposta que isto se faz como "condição para a vida", deve-se ter presente, que seria um reducionismo da perspectiva nietzschiana querer entender o esforço do intelecto para interpretar o mundo apenas como "condições para a vida".

De acordo com Nietzsche, "a realidade consiste a cada vez no particular jogo-conjunto de ações e reações conduzido no interior de complexas formações de centros de força". E, nesse jogo, o que cada ser vivente pretende é tornar-se senhor deste mundo, das coisas, para o que ele lança mão do intelecto. Nesse contexto, "condições para a vida" deve significar condições 
para a sua "expansão". Nessa relação, disposto como conflito, também o conhecer tem uma função instrumental, pois ele mesmo é sempre algo que se dispõe por alguma finalidade. Conhecer é sempre conhecer algo em uma relação de vontade de poder, como meio para se conseguir estabelecer uma dominação, para se obter mais poder: "o conhecimento trabalha como instrumento do poder" . E a linguagem, que surge no contexto do "anseio por poder de formações de domínio", isto é, no contexto de uma interpretação, é, ela mesma, "uma maneira de expressão do querer-poder" .

A compreensão da expressão "condição para a vida", pela qual se dá o processo de reconhecimento da realidade, não pode deixar margem à idéia de uma "tendência de autoconservação", ou da própria vida como simples "adaptação". Todo esse processo se dá como meio de expansão de poder, como forma de se assenhorar de algo.

As ações do intelecto estão numa relação de subordinação às nossas estimativas de valor, que expressam nosso impulso para poder. Em um fragmento de 1885, Nietzsche afirma que, por sua vez, "nossos impulsos são reduzíveis à vontade de poder" e, também, que "a vontade de poder é o fato último, para o qual somos tragados". Portanto, a linguagem é também "vontade de poder e nada além disso".

Mas, porque a própria linguagem simula unidades, ela acaba, normalmente, sendo compreendida como uma articulação de coisas que podem ser "apreendidas" como "entes", numa evidente superestimação da capacidade do intelecto. É justamente aqui, segundo Nietzsche, que se inicia um problema que culmina em estabelecer, como realidade, conceitos como "substância", "predicado", "objeto", "sujeito", "ação", "realidade" etc., isto é, em conceber um mundo metafísico, vale dizer, 'mundo verdadeiro'" . Para Nietzsche, a necessidade metafísica que se criou em relação a conceitos como "ser", "substância", "coisa em si" tem sua origem num tipo de superestimação da linguagem, da gramática e também da lógica.

Segundo Nietzsche, esses "mais elevados conceitos" com os quais se articula esta linguagem convertida em uma espécie de metafísica não são nada mais que "conceitos mais vazios" . Não há qualquer "coisa em si". A crença em "algo em si" é a crença em uma ficção, da mesma forma que a crença na possibilidade do conhecimento da "coisa em si" . Esses "conceitos" se originam da necessidade que se tem da linguagem e da cristalização da forma popular de compreender os acontecimentos em um hábito. $O$ povo se habitua a traduzir o mundo por meio de uma "interpretação errada das experiências", separando, por exemplo, a força de sua exteriorização. Por sua vez, os filósofos que não conseguem se distanciar do preconceito popular tomam-no e 0 exageram.

Resumidamente, pode-se fazer uma análise lingüística da emergência daqueles conceitos entendidos como os "mais elevados", que possibilite de- 
monstrar que eles possuem, como pressupostos para o seu "valor em si", apenas uma espécie de crença metafísica. O "eu" é um dos primeiros conceitos básicos que o homem inventa e que aprende a utilizar quando retém na memória "cinco ou seis 'eu não quero"' . Outro conceito é o "ser" (sein), que se produz em oposição ao conceito "nada" (nichts) . Numa decorrência dos conceitos iniciais "eu" e "ser", o homem passa a falar em eu (ego), "alma" e, por fim, chega ao conceito "sujeito". É a experiência da abstração que permite ao homem falar em "sujeito", e é a partir dela que cria outros conceitos como "ente", "substância" etc. É também a partir do conceito "sujeito" que ele estabelece relação com "objetos", "coisas" etc., acrescentando ainda os conceitos de "movimento", que retratam as diferentes relações do "sujeito" com "objetos" e a relação de objetos entre si. A esse conjunto, deve-se remeter a noção de "conhecimento", que indica uma forma peculiar de relação do sujeito com os objetos. Nessa espécie de "fábula", pode-se acrescentar aqueles que afirmam que o "conhecimento" é tornado possível por "categorias", como "causalidade", formas puras como "espaço" e "tempo", que são dadas "a priori", intrínsecas, no "sujeito"...

Para Nietzsche, essa grande corrente de conceitos, que vão se agarrando uns aos outros para se garantir, não possuem qualquer valor de realidade. Eles são, antes, sintomas de que determinada forma de vontade de poder tomou a linguagem a seu serviço, conferiu-lhe um modo determinado de interpretação e teve poder suficiente para apresentar essa forma de interpretação como sendo "a" interpretação, ou melhor, não mais como interpretação, mas como "a" verdade de conceitos que "são" e que não "emergem" de interpretações. Com isto, ela confere uma espécie de função transcendental pura a coisas que tiveram, inicialmente, funções regulativas para a vida.

Apesar de Nietzsche ser um crítico em relação à linguagem, não se deve pensar que ele queira negar seu valor, o valor da gramática, ou do pensar lógico. Tal atitude seria algo sem sentido, pois ele nem poderia articular os conceitos necessários para fazer sua crítica, que, no caso se dirige contra a pretensão que se estabeleceu, no campo da gramática e da lógica, de se produzir e de se utilizar conceitos de validade perene, que remetem a essências. Para ele, os conceitos não "remetem a algo", são apenas indícios, sintomas de dominações e, disposta em seus escritos, a linguagem também deve corresponder à idéia de meio, de instrumento para a desarticulação de formações de poder e para a imposição de novas formas, de novas interpretações.

\section{A elação da genealogia com a história}

O primeiro ponto que deve ser considerado ao se tomar a relação entre genealogia e história, particularmente no que se refere ao texto da Genealogia da Moral, é que o leitor não se encontra diante de uma descrição histórica, de algum "relato histórico", de uma "história dos sistemas éticos", ou 
ainda de qualquer "histónia tradicional" ou "histónia natural da moral" . Nietzsche utiliza a história, serve-se do conhecimento histórico como de um instrumental, de uma ferramenta, assim como se serve da filologia, sem no entanto conferir aos seus escritos o caráter de uma filologia. É para fazer uma crítica do valor dos valores morais - e isto no contexto de um engajamento de Nietzsche - , que ele procede ao levantamento histórico e filológico das condições que possibilitaram a produção desta moral; para isso, leva a efeito sua genealogia (Ahnenforschung).

A pesquisa pela "origem" de algo, como foi visto anteriormente, está ligada ao termo "genealogia" antes mesmo de sua utilização por Nietzsche. No texto de Para a Genealogia da Moral, o sentido de uma busca da gênese é apresentado nos seguintes termos: "...para isso é necessário um conhecimento das condições e circunstâncias nas quais nasceram, sob as quais se desenvolveram e se modificaram" , indicando a busca pelo "solo" de onde se originam e onde se enraízam os valores morais, uma busca por sua proveniência, por sua emergência no "palco dos acontecimentos", o que Nietzsche define também ou como "história da emergência" ; ou, querendo diferenciá-la da história no sentido tradicional, como uma "história efetiva da moral" .

O olhar do genealogista considera "...que algo existente, que de algum modo chegou a se realizar, é sempre reinterpretado para novos fins, requisitado de maneira nova, transformado e redirecionado para uma nova utilidade". Ele parte do princípio "...que todo acontecimento no mundo orgânico é um subjugar e assenhorar-se" e pressupõe ainda "que todo subjugar e assenhorar-se é um novo arranjo, um ajuste, no qual o 'sentido' e a 'finalidade' anteriores são necessariamente obscurecidos ou apagados" .

Considerando que a utilidade de "algo" - como por exemplo "de uma instituição de direito, de um costume social, de um uso político, de uma determinada forma nas artes ou no culto religioso" - é resultado da ação de uma forma específica de vontade de poder que, num determinado momento do jogo, se assenhora de suas regras, impondo-se sobre as demais, o "conhecimento" que o genealogista vai buscar produzir tem a ver com o surgimento deste "algo" enquanto um significado que é resultado dessas forças em conflito. Considerando também que este "algo" entendido como sua utilidade, significado, não é anterior ao conflito, e que sua própria "realidade" é resultado deste conflito ainda não resolvido, não se pode imputar-lhe uma estabilidade, mas concluir que ele possui uma "mudança de formas" (Form-Verwandlungen), caracterizada pela fluidez (flüssig) e, se sua forma é "fluente", "o 'sentido' é mais ainda". "Algo" não é realidade ou "representação" da realidade, "mas todos os fins, todas as utilidades são apenas indícios de que uma vontade de poder se assenhorou de algo menos poderoso e lhe imprimiu o sentido de uma função" . A única realidade é, portanto, aparência, reflexo de "processos de subjugamento" ,e a genealogia, uma sintomatologia. 
Tomando "algo" como um signo e sua histónia como uma "ininterrupta cadeia de signos de sempre novas interpretações e ajustes" , o genealogista irá justamente mostrar que em seu "começo histórico" não há uma "identidade primeira", mas a discórdia e o disparate; que sua construção não pode ser apontada como "obra" da "razão", mas do acaso do jogo; e que, se há um caráter de "necessidade" e de "calculabilidade" no curso desse jogo, isto "não ocorre porque nele vigoram leis, e sim porque faltam absolutamente as leis". Nele, a única "lei" é a da vontade de poder, que em sua busca por assenhorarse, interpretar e impor sua interpretação para todo o resto tira, "a cada instante, sua últimas conseqüências" . É nesse estado de forças em conflito que se tem a emergência de "algo". Uma emergência que pode ser entendida como uma entrada em cena de forças. E a "cena" pode ser entendida como o movimento da distribuição das forças - umas frente às outras, umas sobre as outras - num campo que não é fechado, controlado, mas que se fixa, a cada momento, de diferentes formas, e cuja única regra é o prazer calculado da obstinação pelo reativar incessante do jogo.

A idéia de "algo" associado a um "signo" se opõe diretamente à idéia de "coisa" no sentido aristotélico. Mas Nietzsche não pretende marcar uma diferença somente em relação a Aristóteles, mas a toda uma tradição que vai de Sócrates a Schopenhauer e que se caracteriza pela busca da "essência" exata "da coisa", daquilo que lhe confere uma "identidade", da sua "forma" imóvel e anterior a tudo o que é externo, acidental, sucessivo, daquilo que permanece apesar dos conflitos e astúcias, uma vez que estes últimos só alteram suas afecções exteriores.

A metafísica, ao postular a conservação da "essência" das coisas, está propondo uma forma de se relacionar com os conceitos de "finalidade" e "sentido" que pode ser definida como uma "teleologia da auto-conservação" , pois afirma que todas as coisas têm, por finalidade, permanecer, na essência, aquilo que são. Contra essa idéia, Nietzsche apresenta o princípio do acaso. "O acaso pode encontrar a mais bela melodia" .

A compreensão histórica de "algo", como faz a história tradicional, e também os genealogistas ingleses ou Hegel, respeita o princípio teleológico da metafísica, de que esse "algo" atravessa a história sempre idêntico a si mesmo, estável a partir de um fim já dado de forma essencial em sua origem e de uma tendência a evoluir na direção desse fim. Este "algo", entendido como um ser cuja identidade e evolução se dão por uma determinação intrínseca e que não depende de outrem, ou de fatores externos, é, por isso mesmo, em última instância, subtraído da história, que é um constante dominar e subjugar. O próprio conhecimento de seu "processo histórico", segundo esta forma de se ler a história, só se torna possível graças à ligação entre os conceitos "origem", "fim" e "desenvolvimento".

A oposição que Nietzsche pretende estabelecer é, portanto, entre 
história e metafísica. Mas, para isso, ele precisa resgatar a própria história da égide da metafísica. Ele opõe aos conceitos "estáticos" da metafísica o princípio de que nada se "fixa" na história, mas que a história é um fluir de signos, dominações, enfim, de vontade de poder. Pelo próprio movimento de recolocar algo na história (numa "wirkliche Historie"), o genealogista descobre ainda que este "algo" não tem "essência", justamente porque é "sinal" de um movimento que, como ele, não é "independente", mas que só é concebível em uma relação que tem por princípio a instabilidade. A própria história que 0 genealogista faz não é a história de uma coisa, mas de um "signo". A "coisa", entendida como signo, salta do princípio da estabilidade para o da provisoriedade e se converte, de algo posto e estável, em um sentido provisório. Esse é o significado de resgatar a fluidez de "algo", e isso eqüivale a recolocá-lo na história. "Algo" só é seu sentido, e todo sentido só dura até que outra vontade de poder mais forte lhe imponha uma nova significação.

Considerando a idéia de sintomatologia, o papel do genealogista será o de buscar apontar a constituição de sinais, mostrar as diferentes interpretações que lhes dão sentido, indicando as forças em ação que lhes possibilitaram a emergência, a forma como essas forças jogam, a maneira como lutam, como se esforçam para escapar da degenerescência e recobrar o vigor. Por este movimento de retorno efetivo à história, descobre-se, enfim, que nas "origens", por exemplo, do homem moderno (que se apresenta como o ápice de um "processo civilizatório", como seu "fruto maduro"), não há nada de sublime, mas que ele também é um "fruto tardio", engendrado pela violência e pela crueldade, um alto preço que seu próprio processo de constituição procura ocultar.

É possível desde já perceber o importante papel que desenvolve 0 termo "origem" para o procedimento genealógico. É para distinguir entre uma concepção de "origem" que remete a pesquisa histórica a uma busca por aspectos intrínsecos que se encontram no início de algo, e que se desenvolvem na história rumo a uma perfeição cada vez maior, e outra concepção de origem que remete a movimentos de forças que determinam sentidos e que entende a própria finalidade atual como força - como parte de uma estratégia -, que Nietzsche diferencia, ainda que por um momento, os termos "Herkunft" (para apontar a própria "investigação") e "Ursprung" (para apontar a pesquisa dos outros genealogistas da moral).

$O$ texto mais significativo da utilização demarcada desses termos é o Prólogo de Para a Genealogia da Moral, em que o autor aponta, por um lado, o seu objetivo, que é o de se ocupar com "a origem (Herkunft) de nossos preconceitos morais" e, por outro, o trabalho dos demais genealogistas que se ocupam com "a origem (Ursprung) de nossas impressões morais" . Ele distingue também, por esses termos, suas pesquisas da fase madura (Herkunft) de suas especulações infantis (Ursprung) quando, aos 13 anos, se perguntava 
sobre a origem (Ursprung) do mal e a buscava "atrás do mundo" . A tentativa do "Nietzsche infantil" de ser imoralista foi tão bem sucedida quanto a dos genealogistas ingleses e a de Paul Rée. Em ambos os casos, não se pôde dar conta de fazer uma crítica à moral, pois aceitaram os fundamentos dessa moral no próprio ato de se propor a buscar sua "origem" além deste mundo. Não é também pouco importante o fato de que esse modo de especulação infantil de Nietzsche o tenha conduzido a Deus como origem do mal. Diferentemente, 0 "Nietzsche maduro" vai buscar "neste mundo" as condições de invenção (Erfindung ) dos valores morais, demonstrando que eles não passam de preconceitos, de coisas muito humanas.

A preocupação de Nietzsche com a proveniência (Herkunft) dos valores morais tem início, segundo ele, em Humano Demasiado Humano e, embora faça menção a esses escritos como uma "expressão primeira, modesta e provisória" daquilo que se desdobrará em Para a Genealogia da Moral, devese notar que ele se refere a eles como pesquisa pela "Herkunft". Isto não significa que neles, ou na própria seqüência do texto da Genealogia, ele manterá o uso demarcado desses termos. O que Nietzsche quer deixar claro "nesse momento" , com a utilização diferenciada dos termos "Ursprung" e "Herkunft", é que suas pesquisas, a partir de Humano, Demasiado Humano, são de outra ordem em relação às demais pesquisas sobre a moral; que ali se estabelece algo novo em relação a uma busca que sempre esbarrou nas malhas da metafísica, diga-se, da própria moral.

Nietzsche deixa clara a oposição de seus escritos ao postulado básico da filosofia tradicional, de que na "origem" encontra-se a "verdade" da "coisa", anterior ao conhecimento positivo, às ideologias, ao discurso e à proliferação de erros que a obscureceria. Ao rejeitar a pesquisa da "origem", está rejeitando os postulados de "essência", "identidade", "coisa em si" etc., e, ao tomar a "verdade" de algo como sintoma de uma interpretação, quer chegar não à "origem", mas ao "destrinchamento", "desemaranhamento" do jogo de forças que se encontra na proveniência (Entstehung) de algo, mostrando que onde se via "sacralidade" há um começo "baixo", "impuro".

Uma vez desconstituídas as premissas básicas que norteavam a pesquisa sobre os inícios da moral, uma vez demonstrado que seus pressupostos absolutos eram apenas preconceitos e resultados de jogos de interpretação, Nietzsche pode colocar então a questão: "sob que condições o homem inventou para si os juízos de valor bom e mau? e que valor têm eles?". Tem-se aqui a chave da relação entre a genealogia e a história, pois é a partir dessa questão e desses pressupostos que ele vai olhar para a história: "para isso encontrei e arrisquei respostas diversas, diferenciei épocas, povos, hierarquias dos indivíduos..." ; que ele vai, enfim, dispor do que lhe fora colocado ao alcance das mãos, a fim de revirar as "mesquinharias" presentes na proveniência da moral para fazer aparecer as suas condições de invenção, o interpretar e o apoderarse, dos quais procede o valor de seus valores. 
Em um fragmento de 1885/86, pode-se encontrar uma formulação sintética do princípio-chave da genealogia, de seu desdobramento e do ganho que ela proporciona, qual seja uma liberdade diante da moral: "bem e mal são apenas interpretações, e de modo nenhum algum fato, algum 'em si'. Pode-se descobrir a origem deste tipo de interpretação, pode-se fazer a procura e, com isso, lentamente se libertar da arraigada necessidade (coação) de interpretar moralmente" .

Considerando estes últimos pressupostos, pode-se recolocar, agora em uma nova esfera, a questão da diferença entre genealogia e história a partir de dois pontos básicos:

Primeiro. Enquanto a história tradicional supõe em sua reconstrução do passado "une vérité éternelle, une âme que ne meurt pas, une conscience toujours identique à soi" passível de ser apreendida em sua totalidade, em um movimento contínuo, a genealogia "réintroduit dans le devenir tout ce qu'on avait cru immortel chez l'homme", num esforço que, por um lado, prescinde da história "pour conjurer la chimère de l'origine" e, por outro, precisa se prevenir contra os próprios postulados de origem, verdade em si, continuidade, teleologia etc., da história, para poder servir-se dela. Sua cor deve ser "o cinza", "a coisa documentada, o efetivamente constatável, o realmente havido; em síntese, a longa quase indecifrável escrita hieroglífica do passado moral humano" .

A genealogia pressupõe um trabalho meticuloso que lhe possibilite fugir das simplificações que se fazem para reduzir a realidade a algo compreensível, azul, e manter o que passou na dispersão que lhe é própria, no cinza, na proliferação de acontecimentos que formaram o que aparece como único; mas nem por isso ela deve produzir um comportamento "teso" diante da moral, pois, servindo-se da história, revela que em sua "origem" também "nossa velha moral é coisa de comédia" e nada puro, fantasticamente saído das mãos do criador. Ela se serve da história, e a própria história, entendida então como "história efetiva", lhe possibilita rir das "solenidades da origem".

Para o genealogista, o conhecimento histórico, tanto em sua produção, quanto em sua utilização - por exemplo, para oferecer um "caráter inteligível" ao mundo -, só faz sentido como parte e ramificação de uma forma de vontade de poder. Portanto, ver o mundo "de dentro" equivale a vê-lo como vontade de poder, única "realidade", que permanece no desdobrar do jogo, e filosofar é buscar conhecer a emergência e os jogos de manutenção e desaparecimento das forças neste "palco", envolver-se em sua emergência para poder lá tomar parte, ser legislador, criador de valores.

Segundo. A genealogia não se coloca no palco das discussões com a pretensão de fazer uma "observação desinteressada", o que seria "um absurdo sem sentido", e que é o que pretende o historiador tradicional ao olhar para a história: um saber neutro, insensível, sem escolha e, ao mesmo tempo, sem 
que nada lhe escape, que se pretende objetivo e exato no tratamento dos "fatos". O historiador tradicional toma sua perspectiva como sendo universal e esconde seu querer para mostrar um pretenso querer eterno, que acaba se identificando com a crença na "Providence, aux causes finales et à la teleologie". Diferentemente, pelo fato de que por trás das coisas não há essência, de que elas são sem essência, o único saber aceitável para o genealogista é um saber perspectivo. Portanto, é algo sem sentido, para ele, não querer conferir ao seu saber um caráter perspectivo, buscando, por exemplo, ocultar o lugar desde onde lança seu olhar. Ele não teme conceber seu saber como um saber perspectivo e também não esconde sua opção avaliadora: "moral como conseqüência, como sintoma, máscara, tartuferia, doença, mal-entendido; mas, também, moral como causa, medicamento, estimulante, inibição, veneno" .

Por seu procedimento, que não é simples apresentação de fatos, 0 genealogista faz deliberadamente o que o historiador neutro não pretende fazer (mas faz): ele se envolve com os "fatos", melhor, com os "jogos de interpretação". Sua análise é também avaliação e tentativa de cura. Ela apresenta, por exemplo, um diagnóstico: superestimação da compaixão - que é um caminho para um passivo niilismo - como a doença; mostra sua procedência pelo conhecimento das condições e circunstâncias nas quais nasce, sob as quais se desenvolve e se modifica; e - a partir dessa história da procedência aponta o procedimento necessário para a cura: uma crítica ao próprio valor dos valores morais que seja capaz de fazer a própria moral seguir adiante, dar seus próximos passos, o que é condição para se pensar para além desta moral. Ao procurar, por meio dos signos, identificar a vontade de poder que se assenhorou das regras produzindo significados, o genealogista pretende também dar a essas regras uma nova interpretação, produzir novos significados, pois ele também é vontade de poder atuante.

\section{Notas Bibliográficas}

${ }^{1}$ Stegmaier, 1994, p. 63.

${ }^{2}$ Cf., p. ex., Der Brockhaus: "Sondagem sobre a linhagem, pesquisa dos antepassados, doutrina sobre a origem das relações de parentesco entre pessoas ou famílias...".

${ }^{3}$ Cf.: Stegmaier, 1994, p. 63.

${ }^{4}$ Cf.: Brusotti, 1992, p. 81ss.

${ }^{5} \mathrm{ABM}, 211$.

${ }^{6}$ Deleuze, 1991, p. 2.

${ }^{7} \mathrm{EH}$, Zaratustra, 8.

${ }^{8} \mathrm{GM}$ II, 16.

Revista Diálogo Educacional -v. 1 - n.2 - p.1-170 - jul./dez. 2000 
${ }^{9}$ P. ex.: ABM, 257, GM I, 2 e II, 16.

${ }^{10} \mathrm{ABM}, 211$.

${ }^{11} \mathrm{ABM}, 22$.

${ }^{12}$ Cf.: Deleuze, "Pensamento Nômade". In: Escobar (org.), s/d, p. 13.

${ }^{13} \mathrm{ABM}, 22$.

${ }^{14} \mathrm{ABM}, 9$.

${ }^{15}$ Em ABM, 25, Nietzsche recomenda aos filósofos: "evitem o martírio! O sofrimento 'pela verdade'!". Mais adiante, no mesmo texto, pode-se ler também: "afinal, sabem muito bem que não pode ter importância o fato de vocês terem razão, sabem que nenhum filósofo até hoje teve razão, e que poderia haver uma veracidade mais louvável no pequeno ponto de interrogação que colocarem depois de suas palavras de ordem e doutrinas favoritas (e ocasionalmente de si mesmos) do que em todos os solenes gestos e triunfos diante de promotores e tribunais!".

${ }^{16}$ GM, Prólogo, 7.

${ }^{17}$ GM I, 1.

${ }^{18}$ Cf.: GM, Prefácio, 4.

${ }^{19}$ GM I, 1.

${ }^{20}$ Cf. p. ex.: GM I, 1 e 2.

${ }^{21}$ GM I, 1. Cf.: ABM, 228.

${ }^{22}$ ABM, 228 ["...moralische Tartuferie ist, dies Mal unter die neue Form der Wissenschaftlichkeit versteckt"]. Cf. também: GM II, 11.

${ }^{23}$ Cf. GM I, 1; ABM, 2.

${ }^{24} \mathrm{ABM}, 228$.

${ }^{25}$ Cf.: A, Prefácio, 3.

${ }^{26} \mathrm{GM}$, II, 12.

${ }^{27}$ ABM, 228.

${ }^{28}$ GM, Prefácio, 7.

${ }^{29}$ KSA 11, p. 613.

${ }^{30}$ ABM, 268.

${ }^{31} \mathrm{KSA} 12$, p. 51.

${ }^{32} \mathrm{ABM}$, 268. Cf.: KSA 12, 34 e 105.

${ }^{33} \mathrm{KSA} 11$, p. 661. Cf. também, ABM, 24: "Ó santa simplicidade! Em que curiosa simplificação e falsificação vive 0 homem! (...) Como tornamos tudo claro, livre, leve e simples à nossa volta!...".

${ }^{34}$ KSA 11, p. 167. Cf.: KSA 13, p. 279.

${ }^{35}$ KSA 11, p. 637. Cf., também, p. ex.: KSA 11, p. 164, 645, 701 e KSA 12, p. 369. 
${ }^{36}$ Müller-Lauter, 1974, p. 23 - 24. Ele toma como referência: KSA 13, p. 371.

${ }^{37}$ Cf.: KSA 12, p. 142 e KSA 13, p. 303.

${ }^{38} \mathrm{KSA} 13$, p. 302.

${ }^{39}$ Müller-Lauter, 1974, p. 17.

${ }^{40} \mathrm{KSA} 11$, p. 661.

${ }^{41}$ KSA 12, p. 390.

${ }^{42} \mathrm{CI}$, "A 'razão' na filosofia", 4.

${ }^{43} \mathrm{KSA} 11$, p. 614 - 615.

${ }^{44}$ KSA 11, p. 633. Cf.: GM I, 13.

${ }^{45}$ GM II, 3.

${ }^{46}$ Cf.: KSA 11, p. 64.

${ }^{47}$ Tome-se como exemplo especialmente o parágrafos 13 e os seguintes da Primeira Dissertação da Genealogia, quando Nietzsche apresenta aspectos da "outra origem do 'bom"', lançando mão de uma construção que lhe permite mostrar o caráter perspectivo de valores que se apresentam como perenes e universais.

${ }^{48}$ Stegmaier, 1994, p. 63.

${ }^{49} \mathrm{GM}$, Prefácio, 6.

${ }^{50}$ Cf.: Giacóia, 1989, p. 100.

${ }^{51}$ P. ex.: KSA 11, p. 613 (Entstehungsgeschichte).

${ }^{52} \mathrm{GM}$, Prefácio, 7.

${ }^{53} \mathrm{GM}$ II, 12.

${ }^{54} \mathrm{GM}$ II, 12.

${ }^{55}$ GM II, 12.

${ }^{56}$ KSA 11, p. 654 (Schein).

${ }^{57} \mathrm{GM}$ II, 12 (Uberwältigungsprozessen).

${ }^{58} \mathrm{GM}$ II, 12.

${ }^{59} \mathrm{ABM}, 22$.

${ }^{60}$ Spaemann, 1981, p. 194.

${ }^{61}$ Citado por Spaemann, 1981, p. 195. Como veremos adiante, o acaso é o que rompe com a pretensa linearidade da história.

${ }^{62}$ GM II, 3.

${ }^{63} \mathrm{GM}$, Prefácio, 2.

${ }^{64}$ GM, Prefácio, 4. Nietzsche menciona o livro A origem das impressões morais, do Dr. Paul Rée. 
${ }^{65}$ GM, Prefácio, 3. Cf. AC, 57.

${ }^{66}$ Cf.: Foucault, "A Verdade e as Formas Jurídicas", p. 11.

${ }^{67}$ Lembre-se que o Prólogo à Para a Genealogia da Moral foi feito após o texto (KSB, 8, p. 154. Cf.: Stegmaier, 1994, p. 34).

${ }^{68}$ Cf.: Foucault, "Nietzsche, la généalogie, l'histoire". In: Dits et écrits II, 1994, p. 136ss.

${ }^{69}$ Veja-se, p. ex., "como se fabricam ideais na terra?" In: GM I, 14.

${ }^{70} \mathrm{GM}$, Prefácio, 3.

${ }^{71}$ KSA 12, p. 131s.

${ }^{72}$ Foucault, 1994, p. 146.

${ }^{73}$ Foucault, 1994, p. 147.

${ }^{74}$ Foucault, 1994, p. 140.

${ }^{75}$ GM, Prefácio, 7.

${ }^{76} \mathrm{GM}$, Prefácio, 7.

${ }^{77}$ Cf.: ABM, 36.

${ }^{78} \mathrm{GM}$ III, 12.

${ }^{79}$ Foucault, 1994, 151.

${ }^{80}$ GM, Prefácio, 6.

\section{Referências Bibliográficas}

BROCKHAUS WAHRIG - Deutsches Wörterbuch. 6 Bänden. Hsg. von Gerhard Wahrig u. a. Stuttgart: F. A. Brockhaus Wiesbaden, 1980.

BRUSOTTI, Marco. "Die 'Selbstverkleinerung des Menschen' in der Moderne": Studie zu Nietzsches "Zur Genealogie der Moral". In: Nietzsche-Studien 20: 81-136. Berlin: W. de Gruyter, 1992.

DELEUZE, Gilles. Nietzsche et la philosophie. 8. ed. Paris: PUF, 1991.

-------. "Pensamento Nômade". In: ESCOBAR, Carlos Henrique de (Org.). Por que Nietzsche? Rio de Janeiro: Achiamé, s/d, p. 9 - 17.

FOUCAULT, Michel. "A verdade e as formas jurídicas". In: Cadernos da PUC-RJ - série Letras e Artes - 01/78, Caderno n. 16. Rio de Janeiro: PUC-RJ, 1978.

Nietzsche, la génealogie, l'histoire". In: "Dit etécrits" II: 136-156. Paris: Gallimard, 1994. 
GIACÓIA JR. Oswaldo. "O grande experimento: sobre a oposição entre eticidade (Sittlichkeit) e autonomia em Nietzsche". In: Trans/Form/Ação 12: 85-96. São Paulo, 1989.

MÜLLER-LAUTER, Wolfgang. "Nietzsches Lehre vom Willen zur Macht". In: Nietzsche-Studien, 3: 1-60, Berlin: W. de Gruyter, 1974.

A doutrina da vontade de poder em Nietzsche. Trad. Oswaldo Giacoia Junior. São Paulo: Annablume, 1997.

NIETZSCHE, Friedrich. Sämtliche Werke. Kritische Studienausgabe Herausgegeben von Giorgio Colli und Mazzino Montinari. München/Berlin/ New York: dtv/Walter de Gruyter, 1988. (KSA)

Briefwechsel. Kritische Studienausgabe. Herausgegeben von Giorgio Colli und Mazzimo Montinari. Berlin/New York: W. de Gruyter, 1975-1993. (KSB)

Além do Bem e do Mal. Prelúdio a uma filosofia do futuro. Trad. Paulo César de Souza. São Paulo: Cia. das Letras, 1992. (ABM)

Genealogia da Moral. Um escrito polêmico. Trad. de Paulo César de Souza. São Paulo: Brasiliense, 1987. (GM)

Ecce Hommo. Como alguém se torna o que é. Trad. de Paulo César de Souza. São Paulo: Cia. das Letras, 1995. (EH)

Aurora. 5ae ed. São Paulo: Nova Cultural, 1991. (Col. Os Pensadores). (A)

RÉE, Paul. Ursprung der moralischen Empfindungen. Chemnitz: Ernst Schmeitzner, 1877.

SPAEMANN, Robert; LOW, Remhard. Die Frage Wozu? - Geschichte und Wiederentdeckung des teleologischen Denkens. München/Zürich: R Piper \& Co. Verlag,1981.

STEGMEIER, Werner. Nietzsches 'Genealogie der Moral'. Darmstadt: W B D, 1994. 